\title{
Binding of quercetin and curcumin to human serum albumin in aqueous dimethyl sulfoxide and in aqueous ethanol
}

\author{
Tatyana Usacheva ${ }^{1}$ ( $\cdot$ George Gamov $^{1} \cdot$ Anna Bychkova $^{2} \cdot$ Yuriy Anufrikov $^{3} \cdot$ Anna Shasherina $^{3} \cdot$ Diana Alister $^{1}$. \\ Natalya Kuranova ${ }^{1} \cdot$ Valentin Sharnin $^{1}$
}

Received: 10 June 2021 / Accepted: 14 January 2022 / Published online: 5 March 2022

○ Akadémiai Kiadó, Budapest, Hungary 2022

\begin{abstract}
The paper reports the spectrofluorimetric and calorimetric study of binding of two hydrophobic biologically active molecules with antioxidant ability, flavonoids quercetin, and curcumin, to human serum albumin (HSA) in water, aqueous DMSO $(0.05$ and $0.1 \mathrm{~mol}$. fraction of DMSO), and aqueous ethanol ( $0.05 \mathrm{~mol}$. fraction of EtOH). Both flavonoids induce the quenching of HSA fluorescence. The stability constants of associates, as well as the changes in enthalpy of the reaction between quercetin and protein, were evaluated. The influence of solvent composition and additions of hydroxypropyl- $\beta$-cyclodextrin as a solubilizer of hydrophobic molecules, on the association processes is discussed.
\end{abstract}

Keywords Albumin $\cdot$ Quercetin $\cdot$ Curcumin $\cdot$ Calorimetry $\cdot$ Binding constant $\cdot$ Enthalpy $\cdot$ Mixed solvents

\section{Introduction}

Quercetin (QCT) is a natural flavonol that can be found in plants. It is contained in abundance in apples, honey, raspberries, onions, red grapes, cherries, citrus fruits, and green leafy vegetables [1]. Curcumin (Curc) is a chemical of plant origin (Curcuma longa) as well, used as an herbal supplement, cosmetics ingredient, for food flavoring and coloring. Both compounds are best known for their antioxidant properties. When quercetin reacts with a free radical, it donates a proton and becomes a low-reactive free radical itself stabilized due to the delocalization of electrons by resonance [2]. The antioxidant mechanisms of curcumin include free radicals scavenging as well as modulating the activity of GSH catalase and SOD enzymes active in the neutralization of free radicals; and inhibiting ROS-generating enzymes such as lipoxygenase/cyclooxygenase and xanthine hydrogenase/ oxidase [3].

Tatyana Usacheva

oxt@isuct.rus

1 Ivanovo State University of Chemistry and Technology, Ivanovo, Russia

2 N.M. Emanuel Institute of Biochemical Physics, Russian Academy of Sciences, Moscow, Russia

3 Center for Thermogravimetric and Calorimetric Research, SPbSU Science Park, Saint Petersburg, Russia
Proposed biological activities and historical use of curcumin-containing plants in the traditional medicine of different cultures [4] have led to numerous attempts to use these two chemicals to treat various diseases. Let us limit to the simultaneous use of quercetin and curcumin for the treatment of cancer [5-7], and some other examples describing the treatment of arthritis [8], obesity [9], and radio-protective prophylaxis [10]. Quercetin, along with its derivatives, has been known to be effective in the treatment of viral diseases, such as SARS-CoV-1 [11], Ebola [12], and even SARS-CoV-2 causing COVID-19 [13]. Quercetin and some other small molecules can bound themselves to the spike protein of the virus, interfering with its ability to infect host cells [11]. Quercetin's effect on prophylaxis and treatment of COVID-19 is also a subject of the ongoing clinical trial [14], though a small number of participants (50) and neglecting of randomization makes its results questionable.

Both quercetin and curcumin are PAINs (pan-assay interference compounds), i.e., the molecules showing promising but deceptive activities in various biochemical screenings mainly due to unselective interactions with the target $[15,16]$. Quercetin and curcumin are also poorly soluble in water [17-20], have low stability (especially curcumin $[16,21,22])$, and bioavailability $[16,20]$. One of the ways to enhance the solubility and bioavailability of both compounds and prevent them from decomposing is by encapsulating quercetin or curcumin in the cyclodextrin's cavity 
[20]. Varying the composition of binary aqueous ethanol or aqueous dimethyl sulfoxide solvent may also benefit the solubility and/or stability. We previously studied the reactions between quercetin, curcumin, and hydroxypropyl- $\beta$ cyclodextrin in water-ethanol solvents [23, 24]. Cyclodextrin molecules (CDs) resemble a torus or truncated cone inside it. The inner cavity is hydrophobic while the outer shell is hydrophilic. Due to their structure, CDs are capable of forming inclusion complexes with different hydrophobic organic substrates and improve their solubility. Hydroxypropyl- $\beta$-cyclodextrin $(\mathrm{HP} \beta \mathrm{CD}$ ) and $\beta$-cyclodextrin $(\beta C D)$ are widely used for these purposes. Solvent composition and the host structure should be tuned to guarantee the release of curcumin of quercetin moiety and their binding to the transport protein.

Therefore, the aim of the present paper is to determine the thermodynamic parameters of associates quercetin-human serum albumin (HSA) and curcumin-HSA in aqueous phosphate buffer ( $\mathrm{pH} 7.4)$, in aqueous dimethyl sulfoxide, and in aqueous ethanol. The formulas of small molecules under study are given in Fig. 1.

\section{Experimental}

Quercetin (Sigma-Aldrich, China, $\geq 95 \%$ ), curcumin (Sigma -Aldrich, China, $\geq 65 \%$ ), dimethyl sulfoxide (EKOS-1, Russia, $99.96 \%$ ) were used as purchased. Buffer solution with a pH value of 7.4 was prepared using $\mathrm{Na}_{2} \mathrm{HPO}_{4} \cdot 12 \mathrm{H}_{2} \mathrm{O}$ and $\mathrm{NaH}_{2} \mathrm{PO}_{4} \cdot 2 \mathrm{H}_{2} \mathrm{O}$ (Spektr-Khim, Russia). The acidity of the buffer was controlled potentiometrically.

All the solutions for spectral studies were prepared using bidistilled water $\left(\kappa=3.6 \mu \mathrm{S} \mathrm{cm} \mathrm{cm}^{-1}, \mathrm{pH}=6.6\right)$. The ionic strength value $I=0.25$ was set due to buffer mixture components. The concentration of HSA (A1653, Sigma-Aldrich) in-stock solution stored in the dark place at $4{ }^{\circ} \mathrm{C}$ was controlled prior to experiments by UV-Vis spectroscopy (UV1800, Shimadzu, calibrating plot method) using the known molar extinction coefficient $\varepsilon_{280}=35,700 \mathrm{M}^{-1} \mathrm{~cm}^{-1}$ [25]. Taking into account the poor stability of curcumin $[16,21$, 22] and quercetin [26], only solutions prepared directly before experiments were used.

Fluorescence spectra were registered using the CM2203 setup (Solar Ltd., Belarus) at the excitation wavelength $\lambda_{\mathrm{ex}}=270 \mathrm{~nm}$ in the $280-500 \mathrm{~nm}$ wavelength range. The excitation and emission slit widths were set at 5 and $2 \mathrm{~nm}$, respectively. The quartz cell with an absorbing layer thickness of $1 \mathrm{~cm}$ was used. HSA solution with concentrations of $1.929 \times 10^{-5}$ or $1.0756 \times 10^{-5} \mathrm{~mol} \mathrm{~L}^{-1}$ and volume of $2.7 \mathrm{~mL}$ was placed into the cell and titrated by ten $2 \mu \mathrm{L}$ injections of dimethyl sulfoxide solution of curcumin (1.976 $\left.\times 10^{-3} \mathrm{~mol} \mathrm{~L}^{-1}\right)$ or ethanol solution of quercetin $(2.197 \times$ $\left.10^{-3} \mathrm{~mol} \mathrm{~L}^{-1}\right)$.

Following the recommendations [27-29], all the registered emission spectra of HSA "guest molecule" mixtures (Fig. 2a, c) were corrected for the inner filter effect using the equation:

$F_{\text {cor }}=F_{\text {obs }} \times 10^{0.5\left(\mathrm{~A}_{\mathrm{ex}}+\mathrm{A}_{\mathrm{em}}\right)}$

where $F_{\text {obs }}$ and $F_{\text {cor }}$ are the observed and corrected relative intensities of emission, $A_{\mathrm{ex}}$ and $\underline{A}_{\mathrm{em}}$ are the differences in the absorbance values of the sample upon the addition of the ligand at the excitation $(270 \mathrm{~nm})$ and emission $(280-500 \mathrm{~nm})$ wavelengths, respectively. The absorbance values for quercetin and curcumin solutions were determined using calibrating plot method in the blank experiment. The UV-Vis data are in good agreement with the literature values [30].

Since the solubility of quercetin in water is low, and curcumin solubility is extremely poor, the dimethyl sulfoxide or ethanol solutions of compounds were used. Therefore, we



Fig. 2 Dependence of enthalpic effect on injection number for the binding of quercetin $\left(2 \times 10^{-2} \mathrm{~mol} \mathrm{~L}^{-1}\right)$ by HSA $\left(0.137 \mathrm{~mol} \mathrm{~L}^{-1}\right)$. The experiment was carried out in 5 vol. \% DMSO
Fig. 1 Structural formulas of quercetin (a) and curcumin (b)<smiles>O=c1c(O)c(-c2ccc(O)c(O)c2)oc2cc(O)cc(O)c12</smiles><smiles>COc1cc(/C=C/C(=O)CC(=O)/C=C/c2ccc(O)c(OC)c2)ccc1O</smiles> 
also checked if the observed changes in the luminescence intensity are caused by DMSO or ethanol additions toward protein. The experiments included titration of $2.7 \mathrm{~mL}$ of $1.929 \cdot 10^{-5}$ or $1.0756 \cdot 10^{-5} \mathrm{~mol} \mathrm{~L}^{-1} \mathrm{HSA}$ in phosphate buffer (pH 7.4) by pure non-aqueous solvent. The observed changes in the emission spectrum of albumin were within the error limits of the spectrofluorimeter; therefore, curcumin or quercetin presence was responsible for the alteration of the fluorescence spectra. The maximum mole fraction of the non-aqueous solvent at the end of titration was $c a .0 .002$.

Similarly, the influence of cyclodextrins on the fluorescence spectra of HSA was checked. The aliquot of $2.7 \mathrm{~mL}$ of $1.929 \cdot 10^{-5} \mathrm{~mol} \mathrm{~L}^{-1} \mathrm{HSA}$ in phosphate buffer ( $\mathrm{pH} 7.4$ ) was titrated against the buffer solution of $\beta$-cyclodextrin $(\beta C D$, $1.910 \cdot 10^{-3} \mathrm{~mol} \mathrm{~L}^{-1}$ ). There were ten injections of $10 \mu \mathrm{L}$ each. No changes in the emission spectrum of protein were detected within the error limits of determination. Therefore, no interaction between HSA and $\beta C D$ occurs under the studied experimental conditions. Our results are in good correspondence with the reported data on cyclodextrins (CD)-bovine serum albumin (BSA) and CD-HSA interactions [31-33]. Authors [31-33] specify that the constants of CD-protein association are not to exceed $10^{3}$, which makes the yield of complexes negligible under our experimental conditions.

To calculate the stability constants of quercetin-HSA, curcumin-HSA associates, the spectral data were processed using KEV software [34].

The optimization procedure is based on varying the binding constant until the minimum value of:

$M=\sum_{i=1}^{K}\left(F_{\lambda \max }^{\exp }-F_{\lambda \max }^{\text {calcd }}\right)^{2}$

is reached, where $M$ is a cost function, $K$ is a number of experimental points $F_{\lambda \max }^{\text {exp }}$ and $F_{\lambda \max }^{\text {calcd }}$ are the experimental and calculated fluorescence intensities at the wavelength corresponding to the maximum fluorescence. $F_{\lambda \max }^{\text {calcd }}$ is calculated as follows:

$F=\sum_{j=1}^{N} F_{\mathrm{j}} X_{\mathrm{j}}$

where $F_{\mathrm{j}}$ is a partial fluorescence of the $j$ th component, $X_{\mathrm{j}}$ is a mole fraction of the $j$ th component, $N$ is a number of components (reagents and products). Partial molar properties are found using the linear regression equation.

ITC experiments have been provided by the use of PEAQ ITC (Malvern Pananalytical) calorimetric equipment. HSA solutions for ITC experiments were prepared from the stock protein solution in buffer and used $1 \mathrm{~h}$ after dilution in the buffer-DMSO mixture (5-8 vol.\% of DMSO). DMSO contents did not exceed $8 \%$ to prevent HSA conformational rearrangements monitored by changes in UV-Vis light absorption spectra. Quercetin solutions for ITC experiments were prepared from the stock quercetin solution in DMSO. After preparation of quercetin solution in buffer-DMSO mixture (5-8 vol.\% of DMSO), the solution was centrifuged at $10,000 \mathrm{~g}$ to delete possible aggregates. The supernatants were taken for ITC. HSA and quercetin solutions at a concentration of $5-8 \%$ of DMSO were defined by UV-Vis spectroscopy previously to be used in the ITC experiments. It was checked that the stability of HSA and quercetin solutions was maintained for hours at a concentration of 5-8\% of DMSO after these preparation steps.

PEAQ ITC experiments have been implemented under the following conditions: (1) $0.005-0.015 \mathrm{mM}$ of HSA was in the cell, and $0.100-0.330 \mathrm{mM}$ quercetin was in a syringe; (2) $0.020 \mathrm{mM}$ quercetin was in the cell, and $0.137-0.270 \mathrm{mM}$ of HSA was in a syringe. Similar concentration conditions were followed for blank experiments. The equivalent concentration of 5-8\% of DMSO was taken for solutions prepared for syringe and cell. In the literature for obtaining ITC data, both experimental procedures are used: quercetin titrating to serum albumin [35-37] and serum albumin titrating to quercetin [37]. Therefore, ITC experiments and further calculations on HSA-quercetin binding have been implemented under the following conditions: $0.015 \mathrm{mM}$ of HSA was in the cell, and quercetin $(0.330 \mathrm{mM})$ was in a syringe at 8 vol.\% DMSO. The blank titrations have been carried out for all the cases.

The dependences of enthalpic effects of subsequent injections of titrant into the cell are presented in Fig. 2.

Thermodynamical binding parameters have been estimated with the use of an Independent binding model. The calculations were realized in the frame of Launch Nanoanalyse software included to the Nano ITC $2 \mathrm{G}$ calorimeter by TA Instruments Co. in the SPbSU Science Park, Center for Thermogravimetric and Calorimetric Research. Enthalpy of interaction was determined directly from the calorimetric experiment.

\section{Results and discussion}

The examples of spectrofluorimetric titrations are given in Fig. 3.

The calculations of stability constants from spectrofluorimetric data using KEV are advantageous (comparing to the simple double reciprocal plotting) since they allow checking the different stoichiometry of the products and taking into account the intrinsic fluorescence of associates. The stoichiometric model suggesting a 1:1 reaction between small molecule and protein gives the best fit of the experimental results. 
(a)



(c)



(b)



(d)

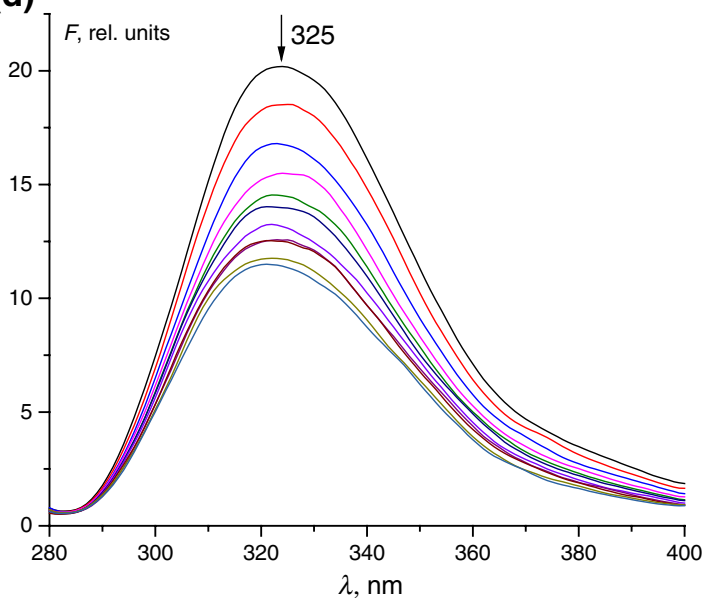

Fig. 3 The changes in fluorescence of HSA upon stepwise addition of a curcumin; $\mathbf{b}-\mathbf{d}$ quercetin in water $(\mathbf{b}), \mathrm{H}_{2} \mathrm{O}-\mathrm{DMSO}\left(X_{\mathrm{DMSO}}=0.05\right.$ mol. fraction) (c), $\mathrm{H}_{2} \mathrm{O}-\mathrm{EtOH}\left(X_{\mathrm{EtOH}}=0.05\right.$ mol. fraction). Spectra were corrected on the inner filter effect

The calculated stability constants are given in Table 1, along with the literature values.

The errors of experimentally determined constant values in Table 1 are the half-width of the confidence intervals at the confidence level of 0.95 and 3-5 parallel experiments.

It is worth noting that we also performed a UV-Vis titration study of the HSA-curcumin interaction in the water. However, the spectra resulting from the graduate adding of curcumin to the protein solution were extremely close to the UV-Vis spectra of free curcumin with the corresponding concentration. The same problem was noticed in the paper [27]. It made the calculations unstable and low-reliable, though the stability constant value of $\lg \beta=4.63 \pm 0.12$ (five replications) at $\mathrm{pH} 7.5(3.90 \pm 0.27$ at three replication and $\mathrm{pH}$ 6.0) are in somewhat agreement with more reliable spectrofluorimetric data (Table 1).

Moreover, the calorimetric titration of quercetin against HSA also returned the value of $\lg K_{\mathrm{b}}=5.75$ confirming the strong affinity of the small molecule to the protein. However, the calorimetric measurements revealed the stoichiometry of the reaction to be $0.2 \mathrm{~mol}$ of quercetin per $1 \mathrm{~mol}$ of protein. The probable reasons are (1) the steric unavailability of the most of potential binding sites caused by the complex spatial structure of protein and by the undetected HSA aggregation in buffer-DMSO solutions, and (2) some aggregation of quercetin due to its limited solubility in buffer-DMSO solutions $[48,49]$. The experimental difficulties related to the measurements of heats of quercetin binding to HSA allow only the estimation of the change in enthalpy of the reaction between quercetin and protein. The value determined in the present paper is $\Delta H_{\mathrm{r}}=-113 \pm 20 \mathrm{~kJ} \mathrm{~mol}^{-1}$.

The values of binding constants of quercetin to serum albumins are close to each other, except for the results of the paper [40], which is clearly an overestimation. The analysis of the existing literature showed a significant difference in the reported stability constants of albumins-curcumin associates. The only thing most of the authors agree on is the stoichiometry being 1:1 in the case of serum 
Table 1 Binding constants of quercetin, curcumin to serum albumins

\begin{tabular}{|c|c|c|c|}
\hline No & $\lg \beta$ & Conditions & Reference \\
\hline \multicolumn{4}{|c|}{ Quercetin } \\
\hline 1 & $5.66 \pm 0.10$ & HSA, spectrofluorimetry, T $298 \mathrm{~K}$, phosphate buffer $\mathrm{pH} 7.4, I=0.25$ & \multirow[t]{4}{*}{ This work } \\
\hline 2 & $5.75 \pm 0.03$ & HSA, spectrofluorimetry, T $298 \mathrm{~K}$, phosphate buffer $\mathrm{pH} 7.4, I=0.25\left(X_{\mathrm{DMSO}}=0.05 \mathrm{~mol}\right.$. fraction $)$ & \\
\hline 3 & $5.69 \pm 0.09$ & HSA, spectrofluorimetry, T $298 \mathrm{~K}$, phosphate buffer $\mathrm{pH} 7.4, I=0.25\left(X_{\mathrm{DMSO}}=0.10 \mathrm{~mol}\right.$. fraction $)$ & \\
\hline 4 & $5.66 \pm 0.06$ & HSA, spectrofluorimetry, T $298 \mathrm{~K}$, phosphate buffer $\mathrm{pH} 7.4, I=0.25\left(X_{\mathrm{EtOH}}=0.05\right.$ mol. fraction $)$ & \\
\hline 5 & 5.32 & HSA, spectrofluorimetry, T $299 \mathrm{~K}$ & [38] \\
\hline 6 & 5.53 & BSA, spectrofluorimetry, T $298 \mathrm{~K}$, HEPES buffer $\mathrm{pH} 7.5, I=0.125$ & [39] \\
\hline \multirow[t]{2}{*}{7} & 7.63 & BSA, cyclic voltammetry, Tris-HCl buffer $\mathrm{pH} 7.4, I=0.05$ & \multirow[t]{2}{*}{ [40] } \\
\hline & 7.53 & BSA, spectrofluorimetry, $T 300-310 \mathrm{~K}$, Tris- $\mathrm{HCl}$ buffer $\mathrm{pH} 7.4, I=0.05$ & \\
\hline 8 & 5.37 & BSA, isothermal titration calorimetry, phosphate buffer $\mathrm{pH} 7.4$ & [41] \\
\hline \multicolumn{4}{|c|}{ Curcumin } \\
\hline 1 & $4.34 \pm 0.05$ & HSA, spectrofluorimetry, T $298 \mathrm{~K}$, phosphate buffer $\mathrm{pH} 7.4, I=0.25$ & This work \\
\hline 2 & $4.74 \pm 0.10$ & HSA, spectrofluorimetry, T $298 \mathrm{~K}$, phosphate buffer $\mathrm{pH} 7.4, I=0.25\left(X_{\mathrm{DMSO}}=0.05 \mathrm{~mol}\right.$. fraction $)$ & This work \\
\hline 3 & $4.48 \pm 0.07$ & HSA, spectrofluorimetry, T $298 \mathrm{~K}$, phosphate buffer $\mathrm{pH} 7.4, I=0.25\left(X_{\mathrm{DMSO}}=0.10 \mathrm{~mol}\right.$. fraction $)$ & This work \\
\hline \multirow[t]{2}{*}{4} & 3.15 & HSA, spectrofluorimetry, T $298 \mathrm{~K}, \mathrm{pH} 7.0$ & \multirow[t]{2}{*}{ [42] } \\
\hline & 3.05 & HSA, isothermal titration calorimetry, T $298 \mathrm{~K}, \mathrm{pH} 7.0$ & \\
\hline 5 & 5.59 & HSA, isothermal titration calorimetry, T $293 \mathrm{~K}$, citrate-phosphate buffer $\mathrm{pH} 7.0, I=0.02$ & [43] \\
\hline \multirow[t]{2}{*}{6} & 5.29 & BSA, spectrofluorimetry, T $298 \mathrm{~K}$, phosphate buffer $\mathrm{pH} 7.0$ & \multirow[t]{2}{*}{ [44] } \\
\hline & 5.97 & BSA, isothermal titration calorimetry, T $298 \mathrm{~K}$, phosphate buffer $\mathrm{pH} 7.0$ & \\
\hline 7 & 5.06 & BSA, spectrofluorimetry, T $298 \mathrm{~K}$, Tris- $\mathrm{HCl}$ buffer $\mathrm{pH} 7.4, I=0.15$ & [45] \\
\hline 8 & 4.52 & BSA, spectrofluorimetry, T $298 \mathrm{~K}$, Tris-HCl buffer $\mathrm{pH} 7.4, I=0.01$ & [46] \\
\hline \multirow[t]{2}{*}{9} & 5.49 & HSA, spectrofluorimetry, T $298 \mathrm{~K}$, phosphate buffer pH 6.4 & \multirow[t]{2}{*}{ [47] } \\
\hline & 6.53 & BSA, spectrofluorimetry, T 298 K, phosphate buffer pH 6.4 & \\
\hline
\end{tabular}

albumin-curcumin interaction. We believe that the most significant reason for the observed discrepancies in the literature is the low stability of curcumin, which forces quick experimental performance to avoid solvolysis [16]. Another way of curcumin degradation is the photolysis; however, since the maxima of excitation and emission do not coincide with the absorbance maximum of curcumin $\left(\lambda_{\max }=430 \mathrm{~nm}\right)$, bleaching is likely avoided in the spectrofluorimetric measurements.

We suppose our stability constants values for the albumin-curcumin complex to be reliable since all the necessary precautions while working with curcumin were taken.

The addition of a small amount of either DMSO or ethyl alcohol does not impact the binding constant of quercetin to HSA (Table 1). Further increasing of the DMSO content leads to protein denaturation [49]. We also observed significant HSA denaturation in aqueous ethanol even at low concentrations of alcohol, which is in agreement with literature data [50]. However, small DMSO addition increases the binding constant of curcumin to HSA (Table 1), which is probably related to the better solvation of curcumin and, especially, their associate. Further increasing of DMSO content leads to a decrease of the association constant, which may reflect the stronger competing for curcumin between protein and a non-aqueous solvent.
In addition to the experiment described above, the titration of HSA solution $\left(2.6 \mathrm{~mL}, 9.8 \times 10^{-6} \mathrm{~mol} \mathrm{~L}^{-1}\right)$ against the mixture of quercetin $\left(1.791 \times 10^{-3} \mathrm{~mol}^{-1}\right)$ and hydroxypropyl- $\beta$-cyclodextrin $\left(9.217 \times 10^{-3} \mathrm{~mol} \mathrm{~L}^{-1}\right)$ was performed (ten injections, $2 \mu \mathrm{L}$ each). Cyclodextrin does not interact with HSA as was found in the separate preliminary experiment; however, it binds quercetin with $\lg \beta=3.46$ as was found spectrophotometrically before. The processing of the results of mixture titration, taking into account the host-guest association between cyclodextrin and quercetin, has returned the same value of $\lg \beta_{\text {quercetin-HSA }}=5.74 \pm 0.09$ (3 parallel experiments).

\section{Conclusions}

The quenching of human serum albumin fluorescence in the presence of increasing amounts of quercetin and curcumin was studied. The binding constants of both compounds to HSA were calculated from the spectrofluorimetric and calorimetric titration data. Quercetin binds strongly to protein with $\lg K_{\mathrm{b}}=5.7-5.8$ units, while curcumin forms much less stable associates with $\lg K_{\mathrm{b}}=4.3-4.7$ units. The addition of either 5 or $10 \mathrm{~mol} \%$ of DMSO or $5 \mathrm{~mol} \%$ of ethanol toward an aqueous solution of quercetin and HSA does not 
affect the value of the association constant. However, small DMSO addition increases the binding constant of curcumin to HSA, which is probably related to the better solvation of curcumin and, especially, its associates. Further increasing of DMSO content leads to a decrease of the association constant, which may reflect the stronger competition for curcumin between protein and a non-aqueous solvent. The change in enthalpy of quercetin binding to HSA was estimated to be $\Delta H_{\mathrm{r}}=-113 \pm 20 \mathrm{~kJ} \mathrm{~mol}^{-1}$.

It was confirmed that hydroxypropyl- $\beta$-cyclodextrin does not interact with HSA. The system containing protein, quercetin, and hydroxypropyl- $\beta$-cyclodextrin is best described with two chemical processes of HSA + quercetin and hydroxypropyl- $\beta$-cyclodextrin + quercetin. Thus, protein and macrocycle only compete for quercetin; the inclusion complex is unable to bind to HSA.

Supplementary Information The online version contains supplementary material available at https://doi.org/10.1007/s10973-022-11216-8.

Acknowledgements The spectrophotometric study was carried out with financial support of Ministry of Science and Higher Education of the Russian Federation (projects FZZW-2020-0009), the fluorescence spectra were registered under grant of Council on grants of the President of the Russian Federation (project MK-923.2022.1.3). The study was carried out using the resources of the Center for Shared Use of Scientific Equipment of the ISUCT (with the support of the Ministry of Science and Higher Education of Russia, Grant № 075-15-2021-671). The calorimetric measurements by PEAQ ITC (Malvern Pananalytical) were carried out at the Center for Precision Genome Editing and Genetic Technologies for Biomedicine, Institute of Gene Biology, Russian Academy of Sciences. The authors are grateful to Doctor Natalia V. Markova, Segment Leader of Malvern Pananalytical for advice on setting up PEAQ ITC experiments.

Authors contributions Conceptualization contributed TU, GG, and VS; Methodology contributed TU, GG, AB, and YA; Formal analysis and investigation contributed GG; AB; YA; AS; DA; NK; Writing-original draft preparation contributed TU, GG, and AB; Writing-review and editing contributed TU and GG; Funding acquisition contributed TU and GG; Resources contributed TU, AB, YA, and AS; Supervision contributed TU, GG, and VS.

\section{Declarations}

Conflict of interest The author's declared that they have no conflict of interest.

\section{References}

1. Hollman PCH, Katan MB. Dietary flavonoids: intake, health effects and bioavailability. Food Chem Toxicol. 1999;37(910):937-42. https://doi.org/10.1016/S0278-6915(99)00079-4.

2. Mariani C, Braca A, Vitalini S, De Tommasi N, Visioli F, Fico G. Flavonoid characterization and in vitro antioxidant activity of Aconitum anthora L. (Ranunculaceae). Phytochemistry. 2008;69(5):1220-6. https://doi.org/10.1016/j.phytochem.2007. 12.009 .
3. Hewlings SJ, Kalman DS. Curcumin: a review of its' effects on human health. Food. 2017;6(10):92. https://doi.org/10.3390/ foods6100092.

4. Gupta SC, Kunnumakkara AB, Aggarwal BB. Curcumin, the holistic avant-garde In: Innovative approaches in drug discovery. Ethnopharmacology, systems biology and holistic targeting. 2017:343-9. https://doi.org/10.1016/B978-0-12-801814-9. 00012-X

5. Srivastava NS, Srivastava RAK. Curcumin and quercetin synergistically inhibit cancer cell proliferation in multiple cancer cells and modulate $\mathrm{Wnt} / \beta$-catenin signaling and apoptotic pathways in A375 cells. Phytomedicine. 2019;52:117-28. https:// doi.org/10.1016/j.phymed.2018.09.224.

6. Altundag EM, Yilmaz AM, Kocturk S, Taga Y, Yalcin AS. Synergistic induction of apoptosis by quercetin and curcumin in chronic myeloid leukemia (K562) cells. Nutr Canc. 2017;70(1):97-108. https://doi.org/10.1080/01635581.2018. 1380208.

7. Liu Y, Wu Y-M, Zhang P-Y. Protective effects of curcumin and quercetin during benzo(a)pyrene induced lung carcinogenesis in mice. Eur Rev Med Pharmacol Sci. 2015;19(9):1736-43.

8. Jackson JK, Higo T, Hunter WL, Burt HM. The antioxidants curcumin and quercetin inhibit inflammatory processes associated with arthritis. Inflamm Res. 2006;55:168-75. https://doi.org/10. 1007/s00011-006-0067-z.

9. Zhao Y, Chen B, Shen J, Wan L, Zhu Y, Yi T, Xiao Z. The beneficial effects of quercetin, curcumin, and resveratrol in obesity. Oxid Med Cell Long. 2017. https://doi.org/10.1155/2017/14594 97.

10. Liang P, Haff RP, Ovchinnikova I, Light DM, Mahoney NE, Kim $\mathrm{JH}$. Curcumin and quercetin as potential radioprotectors and/ or radiosensitizers for X-ray-based sterilization of male navel orangeworm larvae. Sci Rep. 2019;6:2016. https://doi.org/10. 1038/s41598-019-38769-3.

11. Yi L, Li Z, Yuan K, Qu X, Chen J, Wang G, Zhang H, Luo H, Zhu L, Jiang P, Chen L, Shen Y, Luo M, Zuo G, Hu J, Duan D, Nie Y, Shi X, Wang W, Han Y, Li T, Liu Y, Ding M, Deng H, Xu $\mathrm{X}$. Small molecules blocking the entry of severe acute respiratory syndrome coronavirus into host cells. J Virol. 2004;78(20):11334 9. https://doi.org/10.1128/JVI.78.20.11334-11339.2004.

12. Qiu X, Kroeker A, He S, Kozak R, Audet J, Mbikay M, Chretien M. Prophylactic efficacy of quercetin 3-O-D-glucoside against ebolavirus infection. Antimicr Agents Chemother. 2016;60(9):5182-8. https://doi.org/10.1128/AAC.00307-16.

13. Biancatelli RMLC, Berrill M, Catravas JD, Marik PE. Quercetin and vitamin $\mathrm{C}$ : an experimental, synergistic therapy for the prevention and treatment of SARS-CoV-2 related disease (COVID19). Front Immunol. 2020. https://doi.org/10.3389/fimmu.2020. 01451.

14. Effect of Quercetin on Prophylaxis and Treatment of COVID-19. https://clinicaltrials.gov/ct2/show/study/NCT04377789. Accessed 10 June 2021.

15. Glaser J, Holzgrabe U. Focus on PAINS: false friends in the quest for selective anti-protozoal lead structures from Nature? Med Chem Comm. 2016;7:214-23. https://doi.org/10.1039/C5MD0 $0481 \mathrm{~K}$.

16. Nelson KM, Dahlin JL, Bisson J, Graham J, Pauli GF, Walters MA. The essential medicinal chemistry of curcumin. J Med Chem. 2017;60:1620-37. https://doi.org/10.1021/acs.jmedchem.6b009 75 .

17. Tonnesen HH, Masson M, Loftsson T. Studies of curcumin and curcuminoids. XXVII. Cyclodextrincomplexation: solubility, chemical and photochemical stability. Int J Pharm. 2002;244:12735. https://doi.org/10.1016/S0378-5173(02)00323-X.

18. Jagannathan R, Abraham PM, Poddar P. Temperature-dependent spectroscopic evidences of curcumin in aqueous medium: 
a mechanistic study of its solubility and stability. J Phys Chem B. 2012;116:14533-40. https://doi.org/10.1021/jp3050516.

19. Modasiya MK, Patel VM. Studies on solubility of curcumin. Int J Pharm Life Sci. 2012;3(3):1490-7.

20. Riva A, Ronchi M, Petrangolini G, Bosisio S, Allegrini P. Improved oral absorption of quercetin from quercetin phytosome ${ }^{\circledR}$, a new delivery system based on food grade lecithin. Eur J Drug Metab Pharmacokin. 2019;44:169-77. https://doi. org/10.1007/s13318-018-0517-3.

21. Wang Y, Pan M, Cheng A, Lin L, Ho Y, Hsieh C, Lin J. Stability of curcumin in buffer solutions and characterization of its degradation products. J Pharm Biomed Anal. 1997;15:1867-76. https://doi.org/10.1016/S0731-7085(96)02024-9.

22. Griesser M, Pistis V, Suzuki T, Tejera N, Pratt DA, Schneider C. Autoxidative and cyclooxygenase- 2 catalyzed transformation of the dietary chemopreventive agent curcumin. J Biol Chem. 2011;286(2):1114-24.

23. D'Aria F, Serri C, Niccoli M, Mayol L, Quagliariello V, Iaffaioli RV, Biondi $\mathrm{M}$, et al. Host-guest inclusion complex of quercetin and hydroxypropyl- $\beta$-cyclodextrin. J Therm Anal Cal. 2017;130:451-6.

24. Usacheva TR, Kabirov DN, Beregova DA, Gamov GA, Sharnin VA, Biondi M, Mayol L, Giancola C. Thermodynamics of complex formation between hydroxypropyl- $\beta$-cyclodextrin and quercetin in water-ethanol solvents at $T=298.15 \mathrm{~K}$. J Therm Anal Calorim. 2019;138(1):417-24. https://doi.org/10.1007/ s10973-019-08136-5.

25. Chatterjee T, Pal A, Dey S, Chatterjee BK, Chakrabarti P. Interaction of virstatin with human serum albumin: spectroscopic analysis and molecular modeling. PLoS ONE. 2012;7(5):e37468. https://doi.org/10.1371/journal.pone.00374 68.

26. Zenkevich IG, Eshchenko AY, Makarova SV, Vitenberg AG, Dobryakov YG, Utsal VA. Identification of the products of oxidation of quercetin by air oxygenat ambient temperature. Molecules. 2007;12(3):654-72.

27. van de Weert M. Fluorescence quenching to study protein-ligand binding: common errors. J Fluoresc. 2010;20(2):625-9. https:// doi.org/10.1007/s 10895-009-0572-x.

28. van de Weert M, Stella L. Fluorescence quenching and ligand binding: a critical discussion of a popular methodology. J Mol Struct. 2011;998(1-3):144-50. https://doi.org/10.1016/j.molst ruc.2011.05.023.

29. Bakar KA, Feroz SR. A critical view on the analysis of fluorescence quenching data for determining ligand-protein binding affinity. Spectrochim Acta A: Mol Biomol Spec. 2019;223:117337. https://doi.org/10.1016/j.saa.2019.117337.

30. Majhi A, Rahman GM, Panchal S, Das J. Binding of curcumin and its long chain derivatives to the activator binding domain of novel protein kinase C. Bioorg Med Chem. 2010;18:1591-8. https://doi.org/10.1016/j.bmc.2009.12.075.

31. Gao H, Wang Y, Fan Y, Ma J. Interactions of some modified mono- and bis-b-cyclodextrins with bovine serum albumin. Bioorg Med Chem. 2006;14:131-7. https://doi.org/10.1016/j. bmc.2005.08.002.

32. Oi W, Isobe M, Hashidzume A, Harada A. Macromolecular recognition: discrimination between human and bovine serum albumins by cyclodextrins. Macromol Rapid Commun. 2011;32:501-5. https://doi.org/10.1002/marc.201000699.

33. Oftadeh M, Behbahani GR, Saboury AA, Rafiei S. Investigation of the effects of various cyclodextrins on the stabilisation of human serum albumin by a spectroscopic method. Aust J Chem. 2015;68:1894-9. https://doi.org/10.1071/CH15079.

34. Meshkov AN, Gamov GA. KEV: a free software for calculating the equilibrium composition and determining the equilibrium constants using UV-Vis and potentiometric data. Talanta. 2019;198:200-5. https://doi.org/10.1016/j.talanta.2019.01.107.

35. Das P, Chaudhari SK, Das A, Kundu S, Saha C. Interaction of flavonols with human serum albumin: a biophysical study showing structure-activity relationship and enhancement when coated on silver nanoparticles. J Biomol Struct Dyn. 2019;37:1414-26. https://doi.org/10.1080/07391102.2018. 1462732.

36. Precupas A, Sandu R, Popa VT. Quercetin influence on thermal denaturation of bovine serum albumin. J Phys Chem B. 2016;120:9362-75. https://doi.org/10.1021/acs.jpcb.6b06214.

37. Chatziathanasiadou MV, Geromichalou EG, Sayyad N, Vrettos EI, Katsikoudi A, Stylos E, Bellou S, Geromichalos GD, Tzakos AG. Amplifying and broadening the cytotoxic profile of quercetin in cancer cell lines through bioconjugation. Amino Acids. 2018;50:279-91. https://doi.org/10.1007/s00726-017-2514-2.

38. Mondal P, Bose A. Spectroscopic overview of quercetin and its $\mathrm{Cu}$ (II) complex interaction with serum albumins. BioImpacts. 2019;9(2):115-21. https://doi.org/10.15171/bi.2019.15.

39. Skrt M, Benedik E, Podlipnik C, Ulrih NP. Interactions of different polyphenols with bovine serum albumin using fluorescence quenching and molecular docking. Food Chem. 2012;135:2418 24. https://doi.org/10.1016/j.foodchem.2012.06.114.

40. Ni Y, Zhang X, Kokot S. Spectrometric and voltammetric studies of the interaction between quercetin and bovine serum albumin using warfarin as site marker with the aid of chemometrics. Spectrochim Acta A: Mol Biomol Spec. 2009;71:1865-72. https://doi.org/10.1016/j.saa.2008.07.004.

41. Precupas A, Sandu R, Popa VT. Quercetin influence on thermal denaturation of bovine serum albumin. J Phys Chem B. 2016;120(35):9362-75. https://doi.org/10.1021/acs.jpcb.6b062 14.

42. Kar T, Basak P, Sen S, Ghosh RK, Bhattacharyya M. Analysis of curcumin interaction with human serum albumin using spectroscopic studies with molecular simulation. Front Biol. 2017;12:199-209. https://doi.org/10.1007/s11515-017-1449-z.

43. Basu A, Kumar GS. Elucidating the energetics of the interaction of non-toxic dietary pigment curcumin with human serum albumin: a calorimetric study. J Chem Thermodyn. 2014;70:176-81. https://doi.org/10.1016/j.jct.2013.10.037.

44. Hudson EA, de Paula HMC, Ferreira GMD, Ferreira GMD, do Carmo HM, da Silva LHM, dos Pires SAC. Thermodynamic and kinetic analyses of curcumin and bovine serum albumin binding. Food Chem. 2018;242:505-12. https://doi.org/10.1016/j. foodchem.2017.09.092.

45. Hao C, Xu G, Wang T, Lv Z, Zhu K, Li B, Chen S, Sun R. The Mechanism of the Interaction between curcumin and bovine serum albumin using fluorescence spectrum. Russ J Phys Chem B. 2017;11(1):140-5. https://doi.org/10.1134/S199079311 7010043.

46. Bourassa P, Kanakis CD, Tarantilis P, Pollissiou MG, TajmirRiahi HA. Resveratrol, genistein, and curcumin bind bovine serum albumin. J Phys Chem B. 2010;114:3348-54. https://doi. org/10.1021/jp9115996.

47. Mohammadi F, Bordbar A, Divsalar A, Mohammadi K, Saboury AA. Analysis of binding interaction of curcumin and diacetylcurcumin with human and bovine serum albumin using fluorescence and circular dichroism spectroscopy. Protein J. 2009;28:189-96. https://doi.org/10.1007/s10930-009-9184-1.

48. Tjernberg A, Markova N, Griffiths WJ, Hallén D. DMSOrelated effects in protein characterization. J Biomol Screen. 2006;11(2):131-7. https://doi.org/10.1177/1087057105284218 (Epub 2006 Feb 20 PMID: 16490773).

49. Pabbathi A, Patra S, Samanta A. Structural transformation of bovine serum albumin induced by dimethyl sulfoxide and probed by fluorescence correlation spectroscopy and additional 
methods. Chem Phys Chem. 2013;14(11):2441-9. https://doi. org/10.1002/cphc.201300313.

50. Michnik A, Drzazga Z. Effect of ethanol on the thermal stability of human serum albumin. J Therm Anal Cal. 2007;88:449-54. https://doi.org/10.1007/s10973-006-8072-6.
Publisher's Note Springer Nature remains neutral with regard to jurisdictional claims in published maps and institutional affiliations. 